\title{
CANDI BUMIAYU SEBAGAI MEDIA PEMBELAJARAN SEJARAH PADA ZAMAN HINDU BUDHA
}

\author{
Nurhayati \\ Email:s.nurarbitia1@gmail.com \\ Program Studi Pendidikan Sejarah FKIP Universitas Muhammadiyah Palembang.
}

\begin{abstract}
Abstrak
Beberapa benda dilingkungan kita dapat dimanfaatkan sebagai sumber belajar, baik yang dimanfaatkan secara langsung ( by utility resources) ataupun yang dirancang terlebih dahulu ( by design resources ). Sumber belajar yang dimanfaatkan secara langsung (by utility resources)salah satunyaadalah bangunan bersejarah berupa Candi Bumiayu.Menurut AECT dalam Rusman (2010 : 130), Sumber belajar adalah semua sumber baik berupa data, orang, dan wujud tertentu yang dapat digunakan oleh siswa dalam belajar, baik secara terpisah maupun secara terkombinasi sehingga mempermudah siswa dalam mencapai tujuan belajarnya. Lingkungan dalam pembelajaran dapat diartikan sebagai segala sesuatu yang ada di sekolah atau lingkungan kampus atau juga tempat tinggal siswa yang dapat dijadikan sebagai sumber belajar, dengan maksud lebih lanjut bahwa lingkungan tersebut dapat menjadi objek pengamatan, sarana atau tempat melakukan percobaan/penyelidikan dan sebagai tempat mendapatkan informasi. Begitu banyaknya nilai dan manfaat yang dapat diraih dari lingkungan sebagai sumber belajar dalam pendidikan, bahkan hampir semua tema kegiatan dapat dipelajari dari lingkungan.Namun demikian diperlukan adanya kreativitas dan jiwa inovatif dari para dosen untuk dapat memanfaatkan lingkungan sebagai sumber belajar.
\end{abstract}

Kata Kunci: Candi Bumiayu, Media pembelajaran sejarah, Zaman Hindu Budha

\section{Pendahuluan}

Pengajaran merupakan suatu proses sistemik yang meliputi banyak komponen, salah satunya adalah sumber belajar. Dalam arti yang sempit sumber belajar biasanya hanya dikaitkan pada buku-buku bacaan.Padahal pengertian sumber belajar itu sangat luas, lingkungan juga dapat dijadikan sebagai sumber belajar. Begitu banyak lingkungan di sekitar kita yang dapat digunakan sebagai sumber pembelajaran tanpa perlu biaya yang mahal. Beberapa benda dilingkungan kita dapat dimanfaatkan sebagai sumber belajar, baik yang dimanfaatkan secara langsung ( by utility resources ) ataupun yang dirancang terlebih dahulu ( by design resources ).Sumber belajar yang dimanfaatkan secara langsung (by utility resources)salah satunyaadalah bangunan bersejarah berupa Candi Bumiayu.Menurut AECT dalam Rusman (2010 : 130), Sumber belajar adalah semua sumber baik berupa data, orang, dan wujud tertentu yang dapat digunakan oleh siswa dalam belajar, baik secara terpisah maupun secara terkombinasi sehingga 
mempermudah siswa dalam mencapai tujuan belajarnya. Lingkungan dalam pembelajaran dapat diartikan sebagai segala sesuatu yang ada di sekolah atau lingkungan kampus atau juga tempat tinggal siswa yang dapat dijadikan sebagai sumber belajar, dengan maksud lebih lanjut bahwa lingkungan tersebut dapat menjadi objek pengamatan, sarana atau tempat melakukan percobaan/penyelidikan dan sebagai tempat mendapatkan informasi. Begitu banyaknya nilai dan manfaat yang dapat diraih dari lingkungan sebagai sumber belajar dalam pendidikan, bahkan hampir semua tema kegiatan dapat dipelajari dari lingkungan.Namun demikian diperlukan adanya kreativitas dan jiwa inovatif dari para dosen untuk dapat memanfaatkan lingkungan sebagai sumber belajar.

Lingkungan merupakan sumber belajar yang kaya dan menarik.Lingkungan mana pun dapat menjadi tempat yang menyenangkan bagi mahasiswa. Pada saat belajar di kelas mahasiswa diperkenalkan mengenai teori, tetapi dengan memanfaatkan lingkungan mahasiswa akan dapat memperoleh pengalaman yang lebih banyak lagi. Dalam pemanfaatan lingkungan tersebut dosen dapat membawa kegiatan-kegiatan yang biasanya dilakukan di dalam ruangan kelas ke alam terbuka dalam hal ini lingkungan berupa bangunan bersejarah berupa Candi Bumiayu,namun jika dosen hanya menceritakan kisah tersebut dalam ruangan kelas, nuansa yang terjadi di dalam kelas tidak akan sealamiah seperti halnya jika dosen mengajak mahasiswa untuk memanfaatkan lingkungan sekitar, dengan membawa mahasiswa untuk mengamati lingkungan akanmenambah keseimbangan dalam kegiatan belajar. Artinya belajar tidak hanya terjadi di ruangan kelas namun juga dapat dilakukan di luar ruangan kelas,dalam hal ini lingkungan belajarnya berupa bangunan bersejarah yaitu Candi Bumiayu sebagaisumber belajar yang sangat berpengaruh terhadap perkembangan psikologis, keterampilan sosial dan budaya, perkembangan emosional serta intelektual mahasiswa. Dalam lingkungan Candi Bumiayu juga terdapat museum tentang Candi Bumiayu.Sebagai lembaga yang bertugas menyimpan, memelihara serta memamerkan hasil karya, karsa dan cipta manusia sepanjang zaman, museum merupakan tempat yang tepat sebagai sumber pembelajaran bagi kalangan pendidikan, karena melalui benda yang dipamerkan pengunjung dapat belajar tentang berbagai hal yang berkenaan dengan nilai, perhatian serta peri kehidupan manusia.

Para dosen dan mahasiswa dapat memanfaatkan Candi Bumiayu beserta museumnyasecara efektif dengan melakukan kegiatan observasi yang secara tidak langsung dapat menjadi batu loncatan bagi munculnya suatu gagasan dan ide baru karena pada kegiatan ini mahasiswa 
dirangsang untuk menggunakan kemampuannya dalam berfikir kritis secara optimal dengan memandang benda peninggalan bersejarah pada masa lampau.

\section{Metodologi}

\section{Jenis-jenis Lingkungan yang Dapat Dijadikan Sebagai Sumber Belajar}

Pembelajaran yang sedang dikembangkan sekarang adalah pembelajaran yang memanfaatkan lingkungan sebagai sumber belajar yang dikenal dengan pembelajaran konteksual. Dosen dalam mengajar tidak terikat pada buku teks, dan menjelaskan kepada mahasiswa tentang konsep-konsep, istilah-istilah dan teori-teori di dalam kelas secara abstrak dan mahasiswa berusaha untuk memahami jalan pikiran dosen. Dalam pembelajaran konteksual materi pembelajaran yang akan disampaikan oleh dosen dikaitkan dengan lingkungan dan sebagai sumber belajar. Mahasiswa mempelajari materi pelajaran dengan cara memahami konteksnya, sehingga dalam diri mahasiswa akan muncul pemahaman sendiri tentang apa yang dipelajari yang bersifat pengetahuan atau pemahaman dibangun atau dibentuk sendiri oleh mahasiswa bukan hasil dari apa yang dijelaskan oleh dosen. Menurut Ihram Mufid. (2010: diakses 5 April 2019), Pada dasarnya semua jenis lingkungan yang ada di sekitar kita dapat dimanfaatkan untuk mengoptimalkan kegiatan belajar mengajar sepanjang relevan dengan kompetensi dasar dan hasil belajar yangdapat berupa lingkungan alam atau lingkungan fisik, lingkungan sosial dan lingkungan budaya atau buatan.

\section{Lingkungan Alam}

Lingkungan alam atau lingkungan fisik adalah segala sesuatu yang sifatnya alamiah, seperti sumber daya alam (air, hutan, tanah, batu-batuan), tumbuh-tumbuhan dan hewan (flora dan fauna), sungai, iklim, suhu, dan sebagainya. Lingkungan alam sifatnya relatif menetap, oleh karena itu jenis lingkungan ini akan lebih mudah dikenal dan dipelajari oleh mahasiswa. Sesuai dengan kemampuannya, mahasiswa dapat mengamati perubahanperubahan yang terjadi dan dialami dalam kehidupan sehari-hari, termasuk juga proses terjadinya. Dengan mempelajari lingkungan alam ini diharapkan siswa/mahasiswa akan lebih memahami gejala-gejala alam yang terjadi dalam kehidupannya sehari-hari, lebih dari itu diharapkan juga dapat menumbuhkan kesadaran sejak awal untuk mencintai alam, dan mungkin juga ahasiswa dapat turut berpartisipasi untuk menjaga dan memelihara lingkungan alam. 


\section{Lingkungan Sosial}

Selain lingkungan alam sebagaimana telah diuraikan di atas jenis lingkungan lain yang kaya akan informasi yaitu lingkungan sosial. Hal-hal yang dapat dipelajari dalam kaitannya dengan pemanfaatan lingkungan sosial sebagai sumber belajar ini misalnya :

a. mengenal adat istiadat dan kebiasaan penduduk setempat di mana anak tinggal.

b. mengenal jenis-jenis mata pencaharian penduduk di sektiar tempat tinggal dan kampus.

c. Mengenal organisasi-organisasi sosial yang ada di masyarakat sekitar tempat tinggal.

d. Mengenal kehidupan beragama yang dianut oleh penduduk sekitar tempat tinggal.

e. Mengenal kebudayaan termasuk kesenian yang ada di sekitar tempat tinggal dan sekolah.

6. Mengenal struktur pemerintahan setempat seperti RT, RW, desa atau kelurahan dan kecamatan.

Pemanfaatan lingkungan sosial sebagai sumber belajar dalam kegiatan pendidikan sebaiknya dimulai dari lingkungan yang terkecil atau paling dekat dengan mahasiswa.

\section{Lingkungan Budaya}

Di samping lingkungan sosial dan lingkungan alam yang sifatnya alami, ada juga yang disebut lingkungan budaya atau buatan yakni lingkungan yang sengaja diciptakan atau dibangun manusia untuk tujuan-tujuan tertentu yang bermanfaat bagi kehidupan manusia. Anak dapat mempelajari lingkungan buatan dari berbagai aspek seperti prosesnya, pemanfaatannya, fungsinya, pemeliharaannya, daya dukungnya, serta aspek lain yang berkenan dengan pembangunan dan kepentingan manusia dan masyarakat pada umumnya. Agar penggunaan lingkungan ini efektif perlu disesuaikan dengan rencana kegiatan atau program yang ada.Dengan begitu, maka lingkungan ini dapat memperkaya dan memperjelas bahan ajar yang dipelajari dan dapat dijadikan sebagai laboratorium belajar bagi mahasiswa.

\section{Nilai-Nilai Lingkungan sebagai Sumber Belajar}

Lingkungan yang ada di sekitar kita merupakan salah satu sumber belajar yang dapat dioptimalkan untuk pencapaian proses dan hasil pendidikan yang berkualitas. Lebih lanjut Ihram Mufid (2010 : diakses 5 April 2019) menjelaskan tentang nilai-nilai lingkungan sebagai sumber belajar adalah sebagai berikut :

1. Lingkungan menyediakan berbagai hal yang dapat dipelajari mahasiswa. 
Jumlah sumber belajar yang tersedia di lingkungan ini tidaklah terbatas, sekalipun pada umumnya tidak dirancang secara sengaja untuk kepentingan pendidikan. Sumber belajar lingkungan ini akan semakin memperkaya wawasan dan pengetahuan anak karena mereka belajar tidak terbatas oleh empat dinding kelas. Selain itu kebenarannya lebih akurat, sebab mahasiswa dapat mengalami secara langsung dan dapat mengoptimalkan potensi panca inderanya untuk berkomunikasi dengan lingkungan tersebut.

2. Penggunaan lingkungan memungkinkan terjadinya proses belajar yang lebih bermakna sebab mahasiswa dihadapkan dengan keadaan dan situasi yang sebenarnya. Hal ini akan memenuhi prinsip kekonkritan dalam belajar sebagai salah satu prinsip pendidikan.

3. Penggunaan lingkungan sebagai sumber belajar akan mendorong pada penghayatan nilainilai atau aspek-aspek kehidupan yang ada di lingkungannya. Kesadaran akan pentingnya lingkungan dalam kehidupan dapat mulai ditanamkan pada anak sejak dini, sehingga setelah mereka dewasa kesadaran tersebut bisa tetap terpelihara.

4. Menyediakan sumber belajar yang sangat beragam dan banyak pilihan. Kegemaran belajar sejak usia dini merupakan modal dasar yang sangat diperlukan dalam rangka penyiapan masyarakat belajar (learning societes) dan sumber daya manusia di masa mendatang.

\section{Hasil dan Pembahasan}

\section{Sejarah Candi Bumiayu}

Keberadaan Candi Bumiayu di Kecamatan Tanah Abang Kabupaten Penukal Abab Lematang Ilir (PALI) diduga muncul pada abad ke-8 sampai abad ke-9 Masehi dan berkembang hingga abad ke-12 Masehi. Pertanggalan tersebut ditetapkan berdasarkan penelitian Bambang Budi Utomo tahun 1992/1993 serta Suaka Peninggalan Sejarah dan Purbakala Provinsi Jambi, Sumatera Selatan dan Bengkulu pada tahun 1993 terhadap sejumlah peninggalan dan nilai sejarah di situs tersebut. "Antara lain berupa tulisan, pecahan keramik Cina, arca dan bangunan candi" (Utomo, 1992:4). Lebih jauh lagi "pengetahuan mengenai bentuk arsitektur candi dapat digunakan sebagai bahan rujukan untuk mengetahui perkembang gaya arsitektur Candi Bumiayu sebagai salah satu candi di Sumatera khususnya dan Indonesia pada umumnya" (Tim Balai Arkeologi, 1998:15). 
Candi Bumiayu yang berada di Sumatra Selatan, merupakan death monument, artinya monumen yang telah ditinggalkan masyarakat pendukungnya. Candi tersebut ditinggalkan mungkin seiring dengan terdesaknya kekuatan politik Hindu oleh Islam" (Purwanti,1998: 35). Kemudian candi-candi itu rusak dan terkubur dalam tanah hingga ditemukan kembali oleh E.P. Tombrink tahun 1864. Tinggalan monumental itu beserta sistem budayanya benar-benar hilang pula dari ingatan kolektif pewarisnya. Hal itu tampak bahwa penduduk Bumiayu tidak mengenal fungsi candi pada awalnya. Cerita penduduk yang dicatat oleh A.J. Knaap tahun 1902 menyatakan bahwa apa yang sekarang disebut candi di Bumiayu itu adalah bekas istana sebuah kerajaan yang disebut Gedebong Undang. Diceritakan pula bahwa wilayah kerajaan tersebut sampai di Modong dan F.M. Schnitger melaporkan bahwa di kedua desa tersebut terdapat pula tinggalan agama Hindu, namun kini telah hilang terkena erosi Sungai Lematang.

Penduduk Bumiayu pada awalnya tidak mengenal kata candi sebelum ada kegiatan penelitian, perlindungan, dan pemeliharaan di situs tersebut. Kata candi diambil dari bahasa Jawa untuk menggantikan kata kuil dari agama Hindu atau Budha. Namun, orang Jawa yang mewarisi puluhan candi-candi itu pun tidak mengenal lagi pengertian dan fungsi candi yang sebenarnya. Mereka menganggap candi sebagai bangunan pemakaman atau penanaman abu jenazah, bukan kuil dewa Hindu atau Budha. R. Soekmono (1974) melalui disertasinya di Universitas Indonesia membuktikan dengan meyakinkan bahwa apa yang disebut candi itu sebenarnya adalah bangunan kuil dewa sebagaimana yang ada di tanah asalnya, Hindustan.

Selama ditinggalkan oleh pendukungnya, Candi Bumiayu potensial mengalami kerusakan, baik yang disebabkan oleh proses alam maupun tangan manusia. Diperkirakan kerusakannya lebih banyak disebabkan oleh karena tangan manusia. Masyarakat yang tinggal di sekitar Candi Bumiayu belum menyadari tinggalan tersebut sebagai pusaka warisan leluhurnya yang harus dilestarikan. Sebagai buktinya, digunakannya batu bata candi, baik polos maupun berelief, untuk bangunan pemakaman dan masjid di desa setempat. Bapak Hasan Husein (60 tahun) mengakui bahwa batu bata masjid Desa Bumiayu diambil dari sisa bangunan candi nomor lima.

Candi-candi Bumiayu yang ditemukan dalam keadaan demikian itu sejak tahun 1991 telah diupayakan pemanfaatan dan pengembangannya oleh Pemerintah Republik Indonesia. Upaya tersebut dimulai oleh "Pusat Penelitian Arkeologi Nasional dengan melakukan penelitian intensif sejak tahun 1991. Kemudian dilanjutkan oleh Direktorat Perlindungan dan Pembinaan Sejarah dan Purbakala dengan melakukan pemugaran sejak tahun 1992. Kini, seiring dengan otonomi 
daerah, Pemerintah Kabupaten Muaraenim merencanakan pemanfaatan dan pengembangannya untuk kepentingan pariwisata dalam kerangka pembangunan dalam arti yang seluas-luasnya" ( Purwanti,1998: 46).

\section{Pengembangan Cagar Budaya Candi Bumiayu}

Candi Bumiayu ketika ditemukan keadaannya cukup memprihatinkan karena ditinggalkan masyarakat pendukungnya, sehingga mendorong Pemerintah untuk melindungi serta memeliharanya. Hal itu sesuai dengan Undang-undang No. 5 Tahun 1992 Pasal 13 Ayat 1 bahwa setiap orang yang memiliki atau menguasai benda cagar budayawajib melindungi dan memeliharanya. Perlindungan dan pemeliharaannya dilakukan dengan cara penyelamatan, pengamanan, perawatan, dan pemugaran (P.P. No. 10 Tahun 1993 Pasal 23 Ayat 1) dengan memperhatikan nilai sejarah dan keaslian bentuk serta pengamanannya (P.P. No. 10 Pasal 23 Ayat 2). Khusus untuk pelaksanaan pemugaran diberikan rambu-rambu yang lebih jelas lagi dalam Keputusan Menteri Kebudayaan Nomor 063/U/1995 Pasal 12 Ayat 4 bahwa pelaksanaan pemugaran harus memperhatikan prinsip-prinsip pemugaran yang meliputi keaslian bentuk, bahan, pengerjaan, dan tataletak dengan mempertahankan nilai sejarah, ilmu pengetahuan, dan kebudayaan.

Secara hukum telah ada pula upaya pencegahan benda cagar budaya dan situs serta lingkungannya dari kerusakan oleh tangan manusia. Dalam UU No. 5 Tahun 1992 Pasal 15 Ayat 1 dinyatakan bahwa setiap orang dilarang merusak benda cagar budaya dan situs serta lingkungannya. Selanjutnya dalam Pasal 15 Ayat 2 dinyatakan tanpa izin Pemerintah, setiap orang dilarang a. mengambil atau memindahkan benda cagar budaya, baik sebagian maupun seluruhnya, kecuali dalam keadaan darurat; b. mengubah bentuk dan/atau warna serta memugar benda cagar budaya; c. memisahkan sebagian benda cagar budaya dari kesatuannya. Termasuk kegiatan yang dapat merusak benda cagar budaya adalah mengurangi, menambah, memindahkan, dan mencemari benda cagar budaya; dan d. mengurangi, mencemari, dan/atau mengubah fungsi situs .

Rambu-rambu hukum cagar budaya demikian, seharusnya benar-benar dipatuhi dalam upaya pemanfaatan dan pengembangannya. Hal itu mengingat bahwa Candi Bumiayu dan situs serta lingkungannya termasuk sumberdaya yang tidak dapat diperbaharui (non renewable resources). Kecerobohan yang dilakukan tidak hanya menimpa dunia arkeologi, 
melainkan juga bangsa Indonesia secara keseluruhan. Hal itu berarti pula mengingkari maksud dan tujuan dari pemanfaatan dan pengembangan sumberdaya arkeologi itu sendiri.

\section{Pemanfaataan Situs Candi Bumiayu}

Pemanfaatan situs Candi Bumiayu untuk berbagai kepentingan, seperti wisata, kepentingan pendidikan sejarah bangsa dan sebagai objek penelitian.Pemanfaatan situs Candi Bumiayu untuk kepentingan wisata dapat mencapai sasaran bila pengunjung mudah mencapai lokasi, kemudian menyaksikan objek wisata yang asli dalam suasana aman dan nyaman dengan mendapatkan pengetahuan baru yang menarik, dan pulang mendapatkan kesan yang menyenangkan. Keaslian objek wisata merupakan hal yang paling menarik wisatawan. Oleh karena itu, pemugaran candi harus benar-benar memperhatikan undang-undang dan peraturanperaturan yang ada.

Kemudahan mencapai lokasi didukung dengan sarana dan prasarana jalan yang memadai. Keamanan di lingkungan candi harus diwujudkan. Keamanan tidak hanya dalam hal terhindar dari tindak kejahatan, melainkan dari sarana dan prasarana yang terdapat di lingkungan objek wisata. Suasana nyaman dapat diwujudkan dengan penyiapan parkir kendaraan, jalan lingkungan objek wisata, pertamanan, fasilitas pelepas lelah, dan toilet serta terjaganya kebersihan lingkungan. Pengetahuan baru yang menarik disediakan dengan memberi informasi yang singkat, jelas, akurat, dan disajikan dengan bahasa yang sederhana. Untuk membuat informasi demikian perlu mempunyai asumsi bahwa pengunjung adalah orang-orang yang tidak banyak waktu, beraneka ragam tingkat pendidikan, belum mengenal dengan baik Candi Bumiayu dan lingkungannya, dan menginginkan kemudahan.

Pemanfaatan Candi Bumiayu untuk kepentingan pendidikan sejarah bangsa dapat tercapai jika mendapat dukungan dari Dinas Pendidikan Nasional, khususnya guru sejarah di sekolah-sekolah. Tercapainya sasaran pendidikan, termasuk pendidikan sejarah bangsa, dipengaruhi pula oleh kelengkapan media belajarnya. Dalam hal itu perlu juga dimasukkan Candi Bumiayu dalam muatan lokal dari pendidikan sejarah bangsa serta diprioritaskan sebagai tempat widyawisata murid-murid sekolah. Kelayakannya sebagai media belajar dan objek widyawisata anak didik dapat dilihat dari keaslian, nilai sejarah dan budayanya. Candi Bumiayu tidak hanya merupakan bukti kehidupan leluhur bangsa, melainkan juga merupakan simbol yang dapat membangkitkan kesadaran sejarah dan kebanggaan nasional serta memperkuat jatidiri bangsa.

678 | Seminar Nasional Sejarah ke 4 Jurusan Pendidikan Sejarah Universitas Negeri Padang 
Pemanfaatan Candi Bumiayu sebagai objek penelitian tidak hanya mencakup penelitian arkeologi, melainkan juga, berbagai cabang ilmu seperti, arsitektur, teknik, dan biologi. Bagi arkeologi, Candi Bumiayu dan situs serta lingkungannya merupakan bahan kajian arkeologi keruangan (spatial archaeology) untuk mengetahui seluk-beluk teknologi/adaptasi lingkungan, sosial, dan idiologi/religinya. Bagi penelitian arsitektur, Candi Bumiayu dapat dipelajari dari segi pola perancangan dan latar belakangnya. Ilmu teknik sipil dapat meninjauanya dari aspek konstruksi. Sementara itu, peneliti biologi dapat memusatkan perhatian pada spesies lumut, jamur, dan ganggang yang tumbuh pada bangunan candi sekaligus teknologi pembasmiannya yang aman. Penelitian-penelitian tersebut diharapkan menjadi umpan balik bagi pengembangan Candi Bumiayu itu sendiri. Sebelum melaksanakan penelitian harus minta izin kepada Pemerintah, dalam hal ini Kementerian Kebudayaan dan Pariwisata.

\section{Candi Bumiayu Sebagai Sumber Pembelajaran Sejarah}

Menurut Nihza Lutfi, bahwa pengajaran sejarah memiliki tujuan tertentu sebagaimana tercantum dalam Permendiknas nomor 22 tahun 2006, sebagaimana yang kutip oleh Lutfi (2010 : diakses 5 Maret 2019) berikut ini:

1. Membangun kesadaran peserta didik tentang pentingnya waktu dan tempat yang merupakan sebuah proses dari masa lampau, masa kini, dan masa depan;

2. Melatih daya kritis peserta didik untuk memahami fakta sejarah secara benar dengan didasarkan pada pendekatan ilmiah dan metodologi keilmuan.

3. Menumbuhkan apresiasi dan penghargaan pesrta didik terhadap peninggalan sejarah sebagai bukti peradaban bangsa Indonesia di masa lampau;

4. Menumbuhkan pemahaman peserta didik terhadap proses tumbuhnya bangsa Indonesia melalui sejarah yang panjang;

5. Menumbuhkan kesadaran dalam diri peserta didik sebagai bagian dari bangsa Indonesia yang memiliki rasa bangga dan cinta tanah air yang dapat diimplementasikan dalam berbagai kehidupan baik nasional maupun internasional.

Dari tujuan di atas terlihat bahwa sejarah sangat penting untuk diajarkan di sekolah, mulai dari tingkat dasar sampai perguruan tinggi. 
Peninggalan purbakala di Indonesia yang berasal dari masa klasik ada berbagai jenis dan bentuk, salah satu diantaranya berupa bangunan candi. Sebagai salah satu hasil kebudayaan masa lampu banyak aspek yang dapat dikaji dari candi baik dari sisi fungsi, latar belakang keagamaan, masa pendirian dan arsitekturnya. Tinggalan arsitektur ini sendiri merupaka salah satu peninggalan masa lalu yang sangat penting, karena tinggalan arsitektur merupakan tinggalan yang langka. Candi Bumi Ayu merupakan salah satu sumber pembelajaran dalam pendidikan sejarah yang didalamnya juga terdapat museum.Melalui museum diharapkan pendidikan sejarah dalam kerangka menanamkan kesadaran sejarah kepada generasi muda dapat tercapai, karena museum merupakan jendela dunia yang mampu membuka mata kita terhadap sejarah kehidupan bangsa.Melalui museum kita dapat mengetahui bagaimana perjalanan panjang dari bangsa kita, yaitu bangsa Indonesia (Hambali, 2010 : diakses 30 Maret 2019). Koleksi-koleksi museum apabila dimanfaatkan secara maksimal akan dapat mendukung pembelajaran sejarah karena pada dasarnya koleksi-koleksi museum merupakan sebuah sumber belajar sejarah yang nyata. Melalui sumber-sumber belajar yang nyata inilah mahasiswa akan diajak berfantasi ke dunia masa lampau.Menurut Hilgard dalam Holil (2000 : diakses 2 April 20019), "Belajar berhubungan dengan perubahan tingkah laku seseorang terhadap situasi tertentu yang disebabkan oleh pengalaman yang berulang-ulang dalam situasi itu, dimana perubahan tingkah laku tidak dapat dijelaskan atas dasar kecenderungan respon pembawaan, kematangan atau keadaan-keadaan sesaat seseorang (misalnya kelelahan, pengaruh obat dan sebagainya). Sedangkan menurut Gagne "Belajar dapat terjadi apabila suatu situasi stimulus bersama dengan isi ingatan mempengaruhi siswa sedemikian rupa, sehingga perbuatannya (performance) berubah dari waktu sebelum mengalami situasi itu ke waktu sesudah ia mengalami situasi tersebut" (Budiningsih, 2005 : 24). Menurut pandangan modern, belajar adalah proses perubahan tingkah laku berkat interaksi dengan lingkungan. Seseorang dinyatakan melakukan kegiatan belajar setelah ia memperoleh hasil, yakni terjadinya perubahan tingkah laku, seperti dari tidak tahu menjadi tahu, dari tidak mengerti menjadi mengerti dan sebagainya (Holil,2000 :diakses 2 April 2019). Lebih lanjut Holil menjelaskan dalam belajar terdapat 3 tingkatan pengalaman belajar, yaitu : (1) Pengalaman melalui benda sebenarnya; (2) Pengalaman melalui benda-benda pengganti; (3) Pengalaman melalui bahasa.

Dari uraian tersebut menunjukkan bahwa proses pembelajaran tidak hanya berlangsung dalam ruangan kelas saja, tetapi dapat juga berlangsung di lingkungan masyarakat, sehingga 680 | Seminar Nasional Sejarah ke 4 Jurusan Pendidikan Sejarah Universitas Negeri Padang 
benda peninggalan bersejarah berupa Candi Bumiayu dan museum sebagai bagian dari masyarakat merupakan salah satu tempat yang dapat dipilih oleh dosen untuk kegiatan pembelajaran di luar kelas, karena koleksi benda bersejarah dan diorama museum dapat membantu meningkatkan pemahaman mahasiswa terhadap materi pelajaran yang diajarkan di dalam kelas, terutama materi yang berkaitan dengan sejarahpada masa Hindu-Budha. Kunjungan ke situs Bumiayu akan sangat bermanfaat bagi tumbuhnya pemikiran kritis mahasiswa jika dilaksanakan secara terprogram dan terencana dengan baik. Selama mereka berada di situs dan museum, mahasiswa dapat mengamati objek penelitian dan diharapkan pikiran mereka bekerja dan objek pameran yang diamatinya dapat menjadi alat bantu belajar, karena ketika kegiatan ini dilakukan, mahasiswa dirangsang untuk menggunakan kemampuan dalam berfikir kritis.Kemampuan berfikir kritis yang diharapkan dapat muncul ketika dan setelah mahasiswa melakukan kegiatan kunjungan ke objek penelitian dan dapat dicapai jika selama kegiatan kunjungan dosen memberikan bimbingan secara khusus kepada mahasiswa. Mereka tidak dilepas begitu saja dengan pengetahuan yang masih nol tentang materi yang akan dipelajari diSitus Candi Bumiayu dan koleksi museum itu sendiri. Selain itu, dukungan dari pengelola museum sangat diperlukan guna menunjang pencapaian tujuan kunjungan. Sarjuli Soeprapto (2010: 12) menjelaskan bahwa dukungan tersebut dapat dilakukan melalui upaya :

1. Menyediakan panel informasi singkat berkenaan dengan pembagian ruang dan jenis koleksi yang dipamerkannya di pintu masuk museum, sehingga pengunjung dapat memperoleh gambaran isi museum secara lengkap, sehingga walau pengunjung hanya masuk ke salah satu ruangan, tidak akan kehilangan cerita yang disajikan.

2. Menyediakan panel-panel informasi yang disajikan secara lengkap dan menarik sebagai pelengkap benda koleksi pameran dan diorama;

3. Menyediakan berbagai fasilitas penunjang kegiatan pendidikan, seperti leaflet, brosur, buku panduan, film, mikro film, slide dan lembar kerja siswa (LKS), sehingga pengunjung dengan mudah mempelajari objek yang dipamerkan;

4. Khusus berkenaan dengan LKS, perlu dirancang LKS museum yang sesuai dengan kebutuhan masing-masing tingkatan usia siswa serta mampu membangkitkan daya kritis siswa sesuai dengan tingkatannya;

681 | Seminar Nasional Sejarah ke 4 Jurusan Pendidikan Sejarah Universitas Negeri Padang 
5. Museum perlu menyelenggarakan berbagai kegiatan permainan yang menarik dan mampu meningkatkan pemahaman mahasiswa akan objek yang dipamerkan.

Keuntungan dengan dimanfaatkannya peninggalan Situs Candi Bumiayu beserta museumnya sebagai sumber belajar sejarah dalam pengajaran sejarah di kelas dapat membantu dosen dalam memberikan kesempatan kepada mahasiswa dalam mengembangkan ilmu pengetahuan di dalam diri mereka sendiri melalui pengalaman, menemukan dan memahami konsep dalam kehidupan nyata, yang melibatkan peranandosen dan mahasiswa dalam mengembangkan pengetahuan dan bakat sehingga hasil pembelajaran yang diperoleh akan lebih bermakna.

Idealnya belajar itu bukan hanya teori atau verbal saja, tetapi belajar juga dapat mendorong siswa untuk berinteraksi dengan lingkungannya. Hal ini sesuai dengan pengertian belajar, bahwa"belajar ialah suatu proses usaha yang dilakukan seseorang untuk memperoleh suatu perubahan tingkah laku yang baru secara keseluruhan, sebagai hasil pengalamannya sendiri dalam interaksi dengan lingkungannya" (Slameto, 2010:2). Sedangkan menurut Djamarah, kesulitan belajar adalahKondisi dimana anak dengan kemampuan intelekgensi rata-rata atau di atas rata-rata, namun memiliki ketidakmampuan atau kegagalan dalam belajar yang berkaitan dengan hambatan dalam proses pemahaman dan penguasaan diri. Siswa lebih mengerti jikamelihat dari pada hanya mendengar, materi yang diajarkan lebih cepat diserap oleh siswa ketika langsung dalam situasi pengamatan (Djamarah, 2010:50).

\section{Langkah-langkah Dalam Menjadikan Candi Bumiayu sebagai Sumber Pembelajaran Sejarah pada Zaman Hindu Budha}

Candi Bumiayu dapat dijadikan sebagai sumber belajar sebagaimana yang dijelaskan oleh Sukardi, bahwa belajar merupakan "aktivitas pokok yang dilakukan oleh siswa. Dengan belajar siswa akan mengetahui apa yang belum diketahui, sedangkan secara psikologis belajar merupakan proses perubahan tingkah laku untuk mendapatkan pola respon yang baru, yang diperlukan untuk mengadakan interaksi dengan lingkungannya"(Sukardi, 2010:10). Hal ini sesuai dengan pendapat Slameto (2010 : 2) dalam bukunya Belajar dan Faktor-Faktor Yang Mempengaruhinya menyatakan bahwa "belajar ialah suatu proses usaha yang dilakukan seseorang untuk memperoleh suatu perubahan tingkah laku yang baru secara keseluruhan, sebagai hasil pengalamanya sendiri dalam interaksi dengan lingkungannya".Sedangkan menurut 
Sanjaya, sumber belajar adalah "segala sesuatu yang ada di sekitar lingkungan kegiatan belajar yang secara fungsional digunakan untuk membantu optimalisasi hasil belajar" (Sanjaya, 2008:228). Dalam proses pembelajaran sejarah Candi Bumiayu sebagai sumber belajar sejarah pada zaman Hindu Budha dengan langkah-langkah sebagai berikut:

1. Pendahuluan/ Persiapan:

a. Dosen mengumpulkan data-data dan sumber informasi untuk menjadikan Candi Bumiayu sebagai sumber pembelajaran sejarah.

b. Dosen menyesuaikan materi tentang Candi Bumiayu kedalam pokok bahasan pembelajaran dalam sejarah Zaman Hindu Budha.

c. Dosen membuat materi pelajaran sesuai dengan Standar Kompetensi dan Kompetensi dasar.

d. Observasi, setelah dosen menjelaskan tentang Candi Bumiayu di dalam kelas, dosen mengajak mahasiswa berkunjung langsung ke Candi Bumiayu untuk mengetahui keberadaan Situs Candi Bumiayu. Hal ini juga menjadikan salah satu langkahdosen untuk menjadikan Candi Bumiayu sebagai sumber pembelajaran sejarah pada Zaman Hindu Budha.

e. Dosen mengajak mahasiswa berkunjung langsung ke lapangan.

2. Pelaksanaan pengajaran di kelas; dosen menjelaskan tentang keberadaan Candi Bumiayu dan dosen memperlihatkan gambar-gambar tentang Candi Bumiayu sebagai peninggalan agama Hindu-Budha.

3. Penutup atau Tindak Lanjut

a. Tugas; dosen memberikan tugas kepada mahasiswa untuk mengetahui tentang pemahaman mahasiswa terhadap Candi Bumiayu sebagai sumber pembelajaran sejarah. Hal ini juga dapat membantu guru dalam menjadikan Candi Bumiayu sebagaisumber pembelajaran sejarah pada Zaman Hindu Budha.

b. Dosen melakukan analisis terhadap hasil belajar dan memberikan penilaian tentang pemahaman mahasiswa terhadap sejarah zaman Hindu Budha melalui Situs Candi Bumi Ayu.

\section{Simpulan}

683 | Seminar Nasional Sejarah ke 4 Jurusan Pendidikan Sejarah Universitas Negeri Padang 
Candi Bumiayu sebagai benda peninggalan sejarah yang dapat dimanfaatkan sebagai sumber pembelajaran sejarah bersifat nyata dan dapat dibuktikan sampai sekarang. Jadi dapat dikatakan ini Candi Bumiayu sebagai sumber belajar yang tidak dapat diproyeksikan . Adapun manfaat dari peninggalan sejarah adalah :

1. Menambah kekayaan budaya bangsa

2. Menambah pendapatan daerah

3. Bukti nyata peristiwa sejarah

4. Menambah pengetahuan tentang Sejarah Indonesia

Kelebihannya adalah sebagai berikut:

1. Dapat mengetahui benda aslinya

2. Mahasiswa dapat lebih mudah mengapresiasi dan menilai suatu karya sejarah

3. Memudahkan mahasiswa untuk menstimulasikan sendiri suatu peristiwa sejarah melalui peninggalan sejarah.

Kekurangannya adalah:

1. Tidak dapat dibawa ke dalam kelas untuk dipamerkan kepada siswa

2.. Membutuhkan biaya untuk melihat secara langsung

3. Tidak mampu mewakili suatu peristiwasejarah secara keseluruhan

4. Keutuhan dan keasliannya tergantung pada perawatan.

\section{DAFTAR PUSTAKA}

Budiningsih, Asri. 2005. Belajar dan Pembelajaran. Yogyakarta : Rineka Cipta.

Djamarah., Syaiful Bahri dan Zain Aswan 2010. Strategi Belajar Mengajar. Jakarta: Rineka Cipta.

Hambali, Asep. 2010. UpayaMembangkitkan Gairah Sejarah. dikutip dalam http://asephambali.multiply.com/journal/ (diakses 30 Maret 2019)

Holil, Anwar. 2000. Teori Hierarki Belajar. dikutip dalam http://educare.e-fkipunla.net. (Diakses 2 April 2019).

Lutfi, Nihza Al 2010. Pemanfaatan Museum Mahameru Sebagai Sumber Belajar. Semarang : Fakultas Ilmu Sosial Universitas Negeri Semarang 
Mufid, Ihram. 2010. Pemanfaatan Lingkungan Sebagai Sumber Belajar.dikutip dalam http//file:///D:/Pemanfaatan Lingkungan Sebagai Sumber Belajar,htm(diakses 05April 2019)

Peraturan Menteri Pend Nas Republik Indonesia Nomor 22 tahun 2006 tentang Standar Isi.

Purwanti, Retno. 1998. Penelitian Sungai-Sungai di Sekitar Percandian Bumi Ayu Kecamatan Tanah Abang Muara Enim Sumatera Selatan. Palembang: Balai Archeologi Palembang.

Rusman. 2010. Model-model Pembelajaran Kooperatif Mengembangkan Profesionalisme Guru. Bandung : Rajagrafindo Persada.

Sanjaya, Wina. 2008. Perencanaan Desain Sistem Pembelajaran. Jakarta: Rineka Cipta.

Slamento. 2010. Belajar dan Faktor-Faktor yang Mempengaruhinya. Jakarta: Rineka Cipta.

Suprapto, Sarjuli. 2010. Buku Panduan Museum Sultan Mahmud Badaruddin II. Palembang : Dinas Kebudayaan dan Pariwisata Kota Palembang

Sukardi. 2010. Metodologi Penelitian Pendidikan. Yogyakarta: PT Bumi Aksara.

Tim Balai Arkeologi, 1998. Kajian Arkeologi di Sumatera Bagian Selatan. Palembang: Balai Archeologi Palembang.

Utomo, Bambang Budi. 1992. Penelitan Arkeologi Situs Percandian Tanah Abang.

Undang-Undang No. 5 Tahun 1992 tentang Cagar Budaya. 